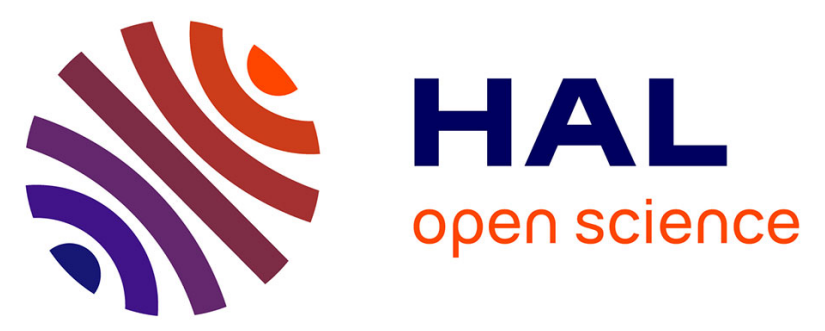

\title{
Formation of methyl radicals derived from cumene hydroperoxide in reconstructed human epidermis: an EPR spin trapping confirmation by using C-substitution
}

Fatma Sahli, Amélie Godard, Bertrand Vileno, Jean-Pierre Lepoittevin, Elena Giménez-Arnau

\section{To cite this version:}

Fatma Sahli, Amélie Godard, Bertrand Vileno, Jean-Pierre Lepoittevin, Elena Giménez-Arnau. Formation of methyl radicals derived from cumene hydroperoxide in reconstructed human epidermis: an EPR spin trapping confirmation by using C-substitution. Free Radical Research, 2019, pp.1-391. 10.1080/10715762.2019.1624741. hal-02151320

\author{
HAL Id: hal-02151320 \\ https://hal.science/hal-02151320
}

Submitted on 7 Jun 2019

HAL is a multi-disciplinary open access archive for the deposit and dissemination of scientific research documents, whether they are published or not. The documents may come from teaching and research institutions in France or abroad, or from public or private research centers.
L'archive ouverte pluridisciplinaire HAL, est destinée au dépôt et à la diffusion de documents scientifiques de niveau recherche, publiés ou non, émanant des établissements d'enseignement et de recherche français ou étrangers, des laboratoires publics ou privés. 


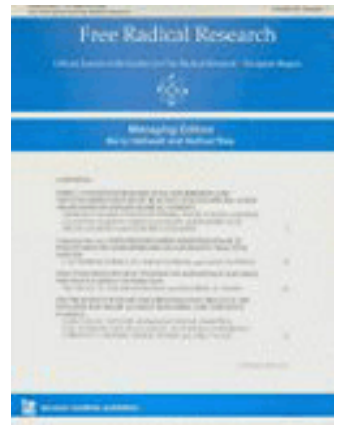

\section{Formation of methyl radicals derived from cumene hydroperoxide in reconstructed human epidermis: an EPR spin trapping confirmation by using 13C-substitution}

\begin{tabular}{|r|l|}
\hline Journal: & Free Radical Research \\
\hline Manuscript ID & GFRR-OM-2019-0062.R1 \\
\hline Manuscript Type: & Original Manuscript \\
\hline Author: & n/a \\
\hline Complete List of Authors: & $\begin{array}{l}\text { Sahli, Fatma; University of Strasbourg, Dermatochemistry, CNRS UMR } \\
\text { 7177, Institut le Bel, 4 Rue Blaise Pascal } \\
\text { Godard, Amélie; University of Strasbourg, Dermatochemistry, CNRS UMR } \\
\text { 7177, Institut le Bel, 4 Rue Blaise Pascal } \\
\text { Vileno, Bertrand; University of Strasbourg, POMAM, CNRS UMR 7177, } \\
\text { Institut le Bel, 4 Rue Blaise Pascal } \\
\text { Lepoittevin, Jean-Pierre; University of Strasbourg, Dermatochemistry, } \\
\text { CNRS UMR 7177, Institut le Bel, 4 Rue Blaise Pascal } \\
\text { Gimenez-Arnau, Elena; University of Strasbourg, Dermatochemistry, } \\
\text { CNRS UMR 7177, Institut le Bel, 4 Rue Blaise Pascal }\end{array}$ \\
\hline Keywords: & $\begin{array}{l}\text { cumene hydroperoxide, skin sensitizers, 13C-substitution, EPR spin- } \\
\text { trapping spectroscopy, reconstructed human epidermis }\end{array}$ \\
\hline & \\
\hline
\end{tabular}

\section{SCHOLARONE" Manuscripts}




\title{
Formation of methyl radicals derived from cumene hydroperoxide in reconstructed human epidermis: an EPR spin trapping confirmation by using ${ }^{13} \mathrm{C}$-substitution
}

\author{
Fatma Sahli, ${ }^{\mathrm{a}}$ Amélie Godard, ${ }^{\mathrm{a}}$ Bertrand Vileno, ${ }^{\mathrm{b}}$ Jean-Pierre Lepoittevin, ${ }^{\mathrm{a}}$ Elena \\ Giménez-Arnau ${ }^{\mathrm{a},}$
}

a Dermatochemistry Laboratory, University of Strasbourg-CNRS UMR 7177, Institut le Bel, 4 Rue Blaise Pascal, 67081 Strasbourg, France

b POMAM Laboratory, University of Strasbourg-CNRS UMR 7177, Institut le Bel, 4 Rue Blaise Pascal, 67081 Strasbourg, France, and French EPR Federation of Research (REseau NAtional de Rpe interDisciplinaire (RENARD, Fédération IR-RPE CNRS \#3443)

Conflicts of interest: none

Corresponding author: Elena Giménez-Arnau, Dermatochemistry Laboratory, University of Strasbourg-CNRS UMR 7177, Institut le Bel, 4 Rue Blaise Pascal, 67081 Strasbourg, France. Phone: +33 3688515 25, E-mail: egimenez@,unistra.fr

\section{ORCIDs:}

Bertrand Vileno: $\quad$ 0000-0001-7527-2068

Elena Giménez-Arnau: 0000-0001-8275-5447 


\begin{abstract}
Dermal exposure to cumene hydroperoxide $(\mathrm{CumOOH})$ during manufacturing processes is a toxicological issue for the industry. Its genotoxicity, mutagenic action, ability to promote skin tumor, capacity to induce epidermal hyperplasia and aptitude to induce allergic and irritant skin contact dermatitis are well known. These toxic effects appear to be mediated through the activation to free radical species such as hydroxyl, alkoxyl and alkyl radicals characterized basically by electron paramagnetic resonance (EPR) and spin-trapping (ST) techniques. To be a skin sensitizer $\mathrm{CumOOH}$ needs to covalently bind to skin proteins in the epidermis to form the antigenic entity triggering the immunotoxic reaction. Cleavage of the $\mathrm{O}-\mathrm{O}$ bond allows formation of unstable $\mathrm{CumO} / \mathrm{CumOO}^{*}$ radicals rearranging to longer half-life specific carbon-centered radicals $\mathrm{R}^{\bullet}$ proposed to be at the origin of the antigen formation. Nevertheless, it is not still clear which $\mathrm{R}^{*}$ are precisely formed in the epidermis and thus involved in the sensitization process. The aim of this work was to elucidate in conditions closer to real-life sensitization which specific $\mathrm{R}^{\cdot}$ are formed in a $3 \mathrm{D}$ reconstructed human epidermis (RHE) model by using ${ }^{13} \mathrm{C}$-substituted $\mathrm{CumOOH}$ at carbon positions precursors of potentially reactive radicals and EPR-ST. We demonstrated that most probably methyl radicals derived from $\beta$-scission of $\mathrm{CumO}^{\bullet}$ radicals occur in RHE through a one-electron reductive pathway suggesting that these could be involved in the antigen formation inducing skin sensitization. We also describe a coupling between nitroxide radicals and $\beta$ position ${ }^{13} \mathrm{C}$ atoms that could be of an added value to the very few examples existing for the coupling of radicals with ${ }^{13} \mathrm{C}$ atoms.
\end{abstract}

Keywords: cumene hydroperoxide, skin sensitizers, ${ }^{13} \mathrm{C}$-substitution, EPR spin-trapping spectroscopy, reconstructed human epidermis 


\section{Introduction}

Cumene hydroperoxide $(\mathrm{CumOOH})$ is produced mainly through the oxidation of cumene in the socalled "cumene process", an industrial procedure for synthesizing phenol and acetone from benzene and propylene based on the acid-catalyzed Hock rearrangement [1]. CumOOH is used as catalyst, curing agent, and initiator in the manufacture of polymers and fiber-reinforced plastics. Plus, it is a strong oxidizing agent making it an important intermediate in the fabrication of epoxy and polyester resin coatings. However, dermal exposure to $\mathrm{CumOOH}$ during manufacturing processes is an important toxicological issue for the industry, currently lacking of regulatory guidelines for occupational exposure limits [2]. CumOOH genotoxicity, mutagenic action and ability to promote skin tumor and induce epidermal hyperplasia have been described [3-5]. CumOOH is also known to cause allergic contact dermatitis (ACD) and has been reported as a significant sensitizer in guinea pigs, with positive specific responses reported in allergy cross-reactivity studies with allergenic cyclohexene hydroperoxides [6]. These toxic effects are believed to be mediated through the activation of the hydroperoxide to radical species such as hydroxyl (HO'), alkoxyl (CumO') and alkyl ( $\left.\mathrm{R}^{*}\right)$ radicals.

Electron paramagnetic resonance (EPR) together with spin-trapping (ST) is a powerful combination for the characterization of transient radicals in chemical and biological systems [7]. Basically, the formed radical (either too short-lived or of too low concentration to be directly detected) reacts with a diamagnetic reagent (spin-trap) to form a more persistent radical (spin-adduct), whose EPR signature can help the characterization of the trapped transient reactive species. EPR-ST has been used for dermatological purposes mainly for the detection of free radicals in UV-irradiated skin, melanoma investigation and in vivo EPR imaging directly in skin of human volunteers [8-10]. EPR-ST has also been used to characterize radicals in isolated mouse keratinocytes and in murine skin treated with CumOOH [11-13]. In addition, EPR-ST proved the formation of in vivo lipid-derived free radicals triggered by $\mathrm{CumOOH}$ when mouse skin was exposed causing severe oxidative stress $[14,15]$. To understand ACD mechanisms for risk assessment purposes, we have proved that EPR-ST is also a 
powerful technique for the detection and identification of radical species derived from sensitizing hydroperoxides (ROOHs) present in consumer products [16-18]. To be skin sensitizers, ROOHs need to covalently bind via radical processes to skin proteins after having penetrated the epidermis, to form this way the antigenic entity trigger of the immunotoxic process. As for the $\mathrm{CumOOH}$ tumor promoting action, initial cleavage of the $\mathrm{O}-\mathrm{O}$ bond forms unstable $\mathrm{RO}^{*} / \mathrm{ROO}^{\bullet}$ radicals that further rearrange to longer half-life carbon centered radicals $\mathrm{R}^{\bullet}$ proposed to be at the origin of the antigen formation $[15,19,20]$. Still, it is not still clear which $\mathrm{R}^{\bullet}$ are precisely formed in the epidermis and thus involved in the sensitization processes.

We have recently reported an EPR-ST methodology allowing to investigate the formation of free radicals issued from skin allergens in a reconstructed human epidermis (RHE) 3D model, thus much closer to what may happen in vivo, by using $\mathrm{CumOOH}$ as proof of concept [21]. RHE are multi-layered keratinocyte cultures, major cell type in the epidermis playing a key role in skin inflammatory reactions. We disclosed that in the EpiSkin ${ }^{\mathrm{TM}}$ RHE model carbon radicals are mainly formed, both by incubating the assay medium and by topical application with CumOOH. Previous in vitro EPR-ST studies reported in keratinocytes cultures suggested these carbon radicals as being methyl radicals issued from $\beta$-scission fragmentation of tertiary alkoxyl radicals ( $\mathrm{CumO}^{\circ}$ ) formed through cleavage of the O-O bond (Scheme 1) [10]. Unlike keratinocytes cultures isolated from skin biopsies, EpiSkin ${ }^{\mathrm{TM}}$ RHE is an in vitro reconstructed human epidermis histologically similar to in vivo human epidermis. It is a complex $3 \mathrm{D}$ structure including a stratum corneum that allows assessing skin penetration concerns with phospholipids and ceramides content influencing the RHE barrier properties [22]. The aim of the present study was to elucidate, in the skin allergy context and in conditions closer to real-life sensitization, if methyl radicals are also formed in EpiSkin ${ }^{\mathrm{TM}} \mathrm{RHE}$ by using ${ }^{13} \mathrm{C}$-substituted $\mathrm{CumOOH}$ derivatives $1\left({ }^{13} \mathrm{C}-\mathrm{MeCumOOH}\right)$ and $2\left(\left({ }^{13} \mathrm{C}-\mathrm{Me}\right){ }_{2} \mathrm{CumOOH}\right)$ (Figure 1$)$, and thus be able to suggest their participation in the formation of the immunogenic complex inducing ACD. 


\section{Materials and methods}

\section{Synthesis of ${ }^{13}$ C-substituted CumOOHs}

${ }^{13} \mathrm{C}-\mathrm{MeCumOOH} 1$ and $\left({ }^{13} \mathrm{C}-\mathrm{Me}\right){ }_{2} \mathrm{CumOOH} 2$ were synthesized ${ }^{13} \mathrm{C}$-substituted at the methyl positions following the synthetic pathway shown in Scheme 2.

\section{Chemicals and instrumentation}

Starting materials were obtained from Sigma-Aldrich (Saint Quentin Fallavier, France) and used as received. ${ }^{13} \mathrm{C}$-Labeled reagents and deuterated solvents were purchased from Euriso-Top (Saint Aubin, France). Air-/moisture-sensitive reactions were conducted in flame-dried glassware under an atmosphere of dry argon. Solvents were dried on alumina, under argon, using a Glass Technology GTS 100 device. Reactions were followed by thin layer chromatography (TLC) on $0.25 \mathrm{~mm}$ silica gel plates $\left(60 \mathrm{~F}_{254}\right.$; Merck, Darmstadt, Germany). After migration, the plates were inspected under UV light (254 $\mathrm{nm}$ ) or sprayed with a solution containing phosphomolybdic acid (5 g), cerium (IV) sulfate (2 g) and sulfuric acid $(12 \mathrm{~mL})$ in water $(188 \mathrm{~mL})$, followed by heating. Column chromatography purifications were performed on silica gel 60 (Merck, Geduran $\left.{ }^{\circledR}, 40-63 \mu \mathrm{m}\right)$. Neutralized silica was prepared by adding to a homogenous water solution of silica gel 60 a saturated solution of $\mathrm{NaHCO}_{3}$ until $\mathrm{pH}$ about 8. After decantation the silica precipitate was washed with water to reach a $\mathrm{pH}$ of 7 , filtered then dried in a oven for at least $24 \mathrm{~h} .{ }^{1} \mathrm{H}$ and ${ }^{13} \mathrm{C}$ NMR spectra were recorded on a Bruker Avance 500 spectrometer at $500 \mathrm{MHz}$ and $125 \mathrm{MHz}$, respectively. Chemical shifts $(\delta)$ are reported in ppm and are indirectly referenced to TMS via the solvent signal $\left(\mathrm{CDCl}_{3}: \delta{ }^{1} \mathrm{H}=7.26, \delta^{13} \mathrm{C}=77.16\right)$. Spectra multiplicities are denoted as $\mathrm{d}$ (doublet), dd (doublet of doublets), $\mathrm{t}$ (triplet) and $\mathrm{m}$ (multiplet).

\section{Synthesis of 1-( $\left.{ }^{13} \mathrm{C}\right)$ acetophenone (4)}

To a suspension of aluminum chloride $(2.07 \mathrm{~g}, 15.5 \mathrm{mmol}, 1.4 \mathrm{eq})$ in anhydrous benzene $(6 \mathrm{~mL})$ at $0^{\circ} \mathrm{C}, 2-\left({ }^{13} \mathrm{C}\right)$ acetyl chloride was added drop wise $(0.8 \mathrm{~mL}, 11.07 \mathrm{mmol}, 1 \mathrm{eq})$ under argon atmosphere. 
Once the addition completed, the mixture was stirred for $17 \mathrm{~h}$ at room temperature. After that time, the mixture was placed into an ice bath and distilled water $(6 \mathrm{~mL})$ was added drop wise until it became white, followed by addition of $\mathrm{HCl} 2 \mathrm{M}(12 \mathrm{~mL})$. The two phases were separated, and the aqueous phase was extracted with diethyl ether $(4 \times 40 \mathrm{~mL})$. The organic phases were combined, washed with brine, dried over $\mathrm{MgSO}_{4}$, filtered and concentrated to obtain $1-\left({ }^{13} \mathrm{C}\right)$ acetophenone (4) as a yellow oil (1.04 g, 8.58 mmol, $77 \%$ yield). CAS Registry Number: [71777-36-1]. ${ }^{1} \mathrm{H}$ NMR $\left(\mathrm{CDCl}_{3}\right) \delta 2.61(\mathrm{~d}$, $\left.3 \mathrm{H},{ }^{1} J_{\mathrm{H} 1-\mathrm{C} 1}=127.6 \mathrm{~Hz}, \mathrm{H} 1\right), 7.44-7.50(\mathrm{~m}, 2 \mathrm{H}, \mathrm{H} 5$ and $\mathrm{H} 7), 7.54-7.60(\mathrm{~m}, 1 \mathrm{H}, \mathrm{H} 6)$, 7.95-7.99 (m, 2H, $\mathrm{H} 4$ and $\mathrm{H} 8) ;{ }^{13} \mathrm{C} \mathrm{NMR}\left(\mathrm{CDCl}_{3}\right) \delta 26.8(\mathrm{C} 1), 128.4(2 \mathrm{C}, \mathrm{C} 5$ and $\mathrm{C} 7), 128.7(2 \mathrm{C}, \mathrm{C} 4$ and $\mathrm{C} 8), 133.2$ (C6), $137.1\left(\mathrm{~d},{ }^{2} J_{\mathrm{C} 3-\mathrm{C} 1}=13.5 \mathrm{~Hz}, \mathrm{C} 3\right), 198.4\left(\mathrm{~d},{ }^{1} J_{\mathrm{C} 2-\mathrm{C} 1}=42.5 \mathrm{~Hz}, \mathrm{C} 2\right)$.

\section{Synthesis of 1-(13C)2-phenylpropan-2-ol (5)}

In a two-necked flask under argon $1-\left({ }^{13} \mathrm{C}\right)$ acetophenone $(4)(450 \mathrm{mg}, 3.71 \mathrm{mmol}, 1 \mathrm{eq})$ was dissolved in $6 \mathrm{~mL}$ of anhydrous tetrahydrofuran at $-78^{\circ} \mathrm{C}$. Methyllithium $\left(2.8 \mathrm{~mL}, 4.46 \mathrm{mmol}, 1.6 \mathrm{M}\right.$ in $\mathrm{Et}_{2} \mathrm{O}, 1.2$ eq) was added drop by drop and the mixture was stirred at $-78{ }^{\circ} \mathrm{C}$ for $21 \mathrm{~h}$ then at room temperature for $5 \mathrm{~h}$. Ammonium chloride was added $(7 \mathrm{~mL})$ and the solution was extracted with diethyl ether $(4 \times 20$ $\mathrm{mL}$ ). Organic phases were combined, dried over $\mathrm{MgSO}_{4}$, filtered and concentrated under reduce pressure to give an orange oil. The crude product was purified by chromatography on silica gel (pentane/EtOAc 9/1 then 5/5) to afford 1-( $\left.{ }^{13} \mathrm{C}\right) 2$-phenylpropan-2-ol (5) as a yellow oil (269.4 mg, 1.96 mmol, $53 \%$ yield). ${ }^{1} \mathrm{H}$ NMR $\left(\mathrm{CDCl}_{3}\right) \delta 1.59\left(\mathrm{~d}, 3 \mathrm{H},{ }^{1} J_{\mathrm{H} 1-\mathrm{C} 1}=126.5 \mathrm{~Hz}, \mathrm{H} 1\right), 1.59\left(\mathrm{~d}, 3 \mathrm{H},{ }^{3} J_{\mathrm{H} 3-\mathrm{C} 1}=4.1\right.$ $\mathrm{Hz}, \mathrm{H} 3), 7.24-7.27(\mathrm{~m}, 1 \mathrm{H}, \mathrm{H} 7), 7.34-7.37$ (m, 2H, H6 and H8), 7.49-7.51 (m, 2H, H5 and H9); ${ }^{13} \mathrm{C}$ $\operatorname{NMR}\left(\mathrm{CDCl}_{3}\right) \delta 31.9\left(2 \mathrm{C}, \mathrm{C} 1\right.$ and C3), $72.7\left(\mathrm{~d},{ }^{1} J_{\mathrm{C} 2-\mathrm{C} 1}=39.3 \mathrm{~Hz}, \mathrm{C} 2\right), 124.5(2 \mathrm{C}, \mathrm{C} 5$ and $\mathrm{C} 9), 126.8$ (C7), 128.4 (2C, C6 and C8), $149.2(\mathrm{C}-4)$.

\section{Synthesis of 1-( $\left.{ }^{13} \mathrm{C}\right)$ cumene hydroperoxide (1)}

To an aqueous solution of hydrogen peroxide $(30 \%, 12.7 \mathrm{~mL})$ at $0^{\circ} \mathrm{C}$, one drop of concentrated sulfuric acid was added. After 30 min stirring, 1-( $\left.{ }^{13} \mathrm{C}\right) 2$-phenylpropan-2-ol (5) (268.1 mg, $1.95 \mathrm{mmol}, 1$ 
eq) was added and the reaction mixture was vigorously stirred at $0^{\circ} \mathrm{C}$ during $4 \mathrm{~h}$, followed by extraction with ethyl acetate $(3 \times 10 \mathrm{~mL})$. The organic layers were combined, dried over $\mathrm{MgSO}_{4}$, filtered, and concentrated under reduce pressure. The crude product was purified by flash chromatography on neutralized silica gel (pentane/EtOAc $85 / 15$ then $50 / 50$ ) to obtain $1-\left({ }^{13} \mathrm{C}\right)$ cumene hydroperoxide (1) as an orange oil $(136.0 \mathrm{mg}, 0.88 \mathrm{mmol}, 32 \%$ yield $) .{ }^{1} \mathrm{H} \mathrm{NMR}\left(\mathrm{CDCl}_{3}\right) \delta 1.62(\mathrm{~d}$, $\left.3 \mathrm{H},{ }^{3} J_{\mathrm{H} 3-\mathrm{C} 1}=4.4 \mathrm{~Hz}, \mathrm{H} 3\right), 1.62\left(\mathrm{~d}, 3 \mathrm{H},{ }^{1} J_{\mathrm{H} 1-\mathrm{C} 1}=127.7 \mathrm{~Hz}, \mathrm{H} 1\right), 7.29-7.34(\mathrm{~m}, 2 \times 1 \mathrm{H}, \mathrm{H} 6$ and H8), 7.38-7.41 (m, 1H, H7), 7.47-7.49 (m, $2 \times 1 \mathrm{H}, \mathrm{H} 5$ and $\mathrm{H} 9) ;{ }^{13} \mathrm{C} \mathrm{NMR}\left(\mathrm{CDCl}_{3}\right) \delta 26.2(2 \mathrm{C}, \mathrm{C} 1$ and $\mathrm{C} 3)$, $84.1\left(\mathrm{~d},{ }^{1} J_{\mathrm{C} 2-\mathrm{C} 1}=39.9 \mathrm{~Hz}, \mathrm{C} 2\right), 125.5(2 \mathrm{C}, \mathrm{C} 5$ and C9), $127.6(\mathrm{C} 7), 128.7$ (2C, C6 and C8), 144.7 (C4). Synthesis of 1,3-(13C)2-phenylpropan-2-ol (6)

Previous synthesis of $\left({ }^{13} \mathrm{C}\right)$ methylmagnesium iodide: in a $50 \mathrm{~mL}$ two-necked flask under argon, magnesium (305 mg, $12.53 \mathrm{mmol}, 1.2 \mathrm{eq}$ ) was flame-dried before to add a spatula tip of iodine and anhydrous diethyl ether $(10 \mathrm{~mL}) .\left({ }^{13} \mathrm{C}\right)$ Methyl iodide $(0.65 \mathrm{~mL}, 10.44 \mathrm{mmol}, 1 \mathrm{eq})$ was then added to the reaction mixture heated slightly with a hairdryer to initiate the reaction. Diethyl ether was added $(10 \mathrm{~mL})$ and the reaction heated again slightly. The reaction mixture was stirred at room temperature during $24 \mathrm{~h}$. A solution of $\left({ }^{13} \mathrm{C}\right)$ methylmagnesium iodide $0.5 \mathrm{M}$ in diethyl ether was in this way obtained.

In a two-necked flask under argon, zinc chloride (79.1 mg, $0.58 \mathrm{mmol}, 0.2 \mathrm{eq})$ was placed and dried under reduced pressure. Lithium chloride $(295.0 \mathrm{mg}, 6.94 \mathrm{mmol}, 2.4 \mathrm{eq})$ was added and the flask was again dried under reduced pressure. To the mixture, (trimethylsilyl)methylmagnesium chloride $(2.30 \mathrm{~mL}, 1.2 \mathrm{mmol}, 0.4 \mathrm{eq})$ was added drop wise at room temperature and the reaction was stirred for 15 min. $\left({ }^{13} \mathrm{C}\right)$ Methylmagnesium iodide $(10 \mathrm{~mL}, 4.9 \mathrm{mmol}, 0.5 \mathrm{M}$ in diethyl ether, $1.7 \mathrm{eq})$ was then added drop wise and the reaction stirred for $45 \mathrm{~min}$ and then cooled to $0^{\circ} \mathrm{C} .1-\left({ }^{13} \mathrm{C}\right)$ Acetophenone (4) (350 mg, $2.89 \mathrm{mmol}, 1 \mathrm{eq}$ ) was added during $1 \mathrm{~h}$ with the use of a syringe pump and the reaction was stirred for $3 \mathrm{~h}$ at $0^{\circ} \mathrm{C}$. After this time, the reaction mixture was quenched with ammonium chloride (10 
$\mathrm{mL})$, extracted with ethyl acetate $(3 \times 10 \mathrm{~mL})$ and washed with brine $(10 \mathrm{~mL})$. The organic phases were combined and dried over $\mathrm{MgSO}_{4}$, filtered and concentrated under reduced pressure to obtain an orange oil. The crude product was purified by chromatography on silica gel (pentane/EtOAc 92/8) and 1,3$\left({ }^{13} \mathrm{C}\right) 2$-phenylpropan-2-ol (6) was obtained as a yellow oil (303.7 mg, $2.19 \mathrm{mmol}, 76 \%$ yield). ${ }^{1} \mathrm{H}$ NMR $\left(\mathrm{CDCl}_{3}\right) \delta 1.59\left(\mathrm{dd}, 3 \mathrm{H},{ }^{1} J_{\mathrm{H} 1 / 3-\mathrm{C} 1 / 3}=121.3 \mathrm{~Hz},{ }^{3} J_{\mathrm{H} 1 / 3-\mathrm{C} 1 / 3}=1.7 \mathrm{~Hz}, \mathrm{H} 1\right.$ or $\left.\mathrm{H} 3\right), 1.59\left(\mathrm{~d}, 3 \mathrm{H},{ }^{1} J_{\mathrm{H} 1 / 3-\mathrm{C} 1 / 3}=\right.$ 130.7 Hz, H-1 or H-3), 7.25-7.28 (m, 1H, H7), 7.34-7.37 (m, 2H, H6 and H8), 7.50-7.51 (m, 2H, H5 and H9); ${ }^{13} \mathrm{C} \mathrm{NMR}\left(\mathrm{CDCl}_{3}\right) \delta 31.8(2 \mathrm{C}, \mathrm{C} 1$ and $\mathrm{C} 3), 74.0\left(\mathrm{t},{ }^{1} J_{\mathrm{C} 2-\mathrm{C} 1 / 3}=38.9 \mathrm{~Hz}, \mathrm{C} 2\right), 124.5(2 \mathrm{C}, \mathrm{C} 5$ and C9), 126.8 (C7), 128.3 (2C, C6 and C8), 149.2 (C4).

\section{Synthesis of 1,3- $\left({ }^{13} \mathrm{C}\right)$ cumene hydroperoxide (2)}

To an aqueous solution of hydrogen peroxide $(30 \%, 7.5 \mathrm{~mL})$ was added at $0^{\circ} \mathrm{C}$ one drop of concentrated sulfuric acid. After $30 \mathrm{~min}, 1,3-\left({ }^{13} \mathrm{C}\right) 2$-phenylpropan-2-ol (6) (155.9 mg, $\left.1.13 \mathrm{mmol}, 1 \mathrm{eq}\right)$ was added and the reaction mixture was vigorously stirred at $0^{\circ} \mathrm{C}$ during $4 \mathrm{~h}$, followed by extraction with ethyl acetate $(3 \times 10 \mathrm{~mL})$. The organic layers were combined, dried over $\mathrm{MgSO}_{4}$, filtered, and concentrated under reduce pressure. The crude product was purified by flash chromatography on neutralized silica gel (pentane/EtOAc 5/1 and 1/1) to obtain 1,3- $\left({ }^{13} \mathrm{C}\right)$ cumene hydroperoxide (2) as an orange oil (36.7 mg, $0.24 \mathrm{mmol}, 21 \%$ yield). ${ }^{1} \mathrm{H} \mathrm{NMR}\left(\mathrm{CDCl}_{3}\right) \delta 1.62\left(\mathrm{~d}, 3 \mathrm{H},{ }^{1} J_{\mathrm{H} 1 / 3-\mathrm{C} 1 / 3}=123.8 \mathrm{~Hz}\right.$, H1 or H3), $1.62\left(\mathrm{~d}, 3 \mathrm{H},{ }^{1} J_{\mathrm{H} 1 / 3-\mathrm{C} 1 / 3}=132.1 \mathrm{~Hz}, \mathrm{H} 1\right.$ or H3), 7.29-7.32 (m, 1H, H7), 7.37-7.41 (m, 2H, H6 and $\mathrm{H} 8), 7.47-7.49(\mathrm{~m}, 2 \mathrm{H}, \mathrm{H} 5$ and $\mathrm{H} 9) ;{ }^{13} \mathrm{C} \mathrm{NMR}\left(\mathrm{CDCl}_{3}\right) \delta 26.2(2 \mathrm{C}, \mathrm{C} 1$ and $\mathrm{C} 3), 84.1\left(\mathrm{t},{ }^{1} J_{\mathrm{C} 2-\mathrm{C} 1 / 3}=\right.$ 39,9 Hz, C2), 125.5 (2C, C5 and C9), 127.6 (C7), 128.7 (2C, C6 and C8), 144.7 (C4).

\section{EPR studies in solution}

CumOOH was purchased from Sigma-Aldrich (Saint-Quentin Fallavier, France) and used as received. DEPMPO was synthesized as reported in the literature [23]. HEPES ( $\geq 99.5 \%$ ), ferrous sulfate heptahydrate $\mathrm{FeSO}_{4} .7 \mathrm{H}_{2} \mathrm{O}$ and acetonitrile $\mathrm{CH}_{3} \mathrm{CN}(99.8 \%)$ were acquired from Sigma-Aldrich (SaintQuentin Fallavier, France). Aqueous solutions were prepared with deionized water. HEPES buffer 
solution (10 mM, pH 6.8) was prepared by dissolving $1.19 \mathrm{~g}$ HEPES in $400 \mathrm{~mL}$ deionized water, with additional $4 \mathrm{~g} \mathrm{NaCl}$ and $0.1 \mathrm{~g} \mathrm{KCl}$. To attain $\mathrm{pH} 6.8 \mathrm{NaOH}$ pellets were added. If the $\mathrm{pH}$ went too high, it was lowered back by carefully adding $\mathrm{HCl}(2 \mathrm{M})$ until $\mathrm{pH}$ remained stable to 6.8. Deionized water was added for a final volume of $500 \mathrm{~mL}$. Stock solutions were prepared for $\mathrm{CumOOH},{ }^{13} \mathrm{C}$ $\mathrm{MeCumOOH}$ and $\left({ }^{13} \mathrm{C}-\mathrm{Me}\right)_{2} \mathrm{CumOOH}\left(10 \mathrm{mM}, \mathrm{HEPES} / \mathrm{CH}_{3} \mathrm{CN}\right.$ 9/1), DEPMPO (100 mM in HEPES) and $\mathrm{FeSO}_{4} \cdot 7 \mathrm{H}_{2} \mathrm{O}\left(10 \mathrm{mM}\right.$ in HEPES). $12.5 \mu \mathrm{L}$ of DEPMPO solution were mixed with $\mathrm{FeSO}_{4} \cdot 7 \mathrm{H}_{2} \mathrm{O}$ $(0.5 \mu \mathrm{L}$ for a final $0.1 \mathrm{mM}$ concentration in the reaction mixture $), 5 \mu \mathrm{L}$ of the hydroperoxide solution added and final volume completed to $50 \mu \mathrm{L}$. This way, final concentrations in the reaction mixture were $25 \mathrm{mM}$ spin-trap and $0.54 \mathrm{mM}$ hydroperoxide. The reaction mixture was subjected to stirring and further introduced into the EPR quartz capillary tube.

\section{EPR studies in reconstructed human epidermis}

EpiSkin $^{\mathrm{TM}}$ (Lyon, France; $0.38 \mathrm{~cm}^{2}$ ) is a RHE from normal human keratinocytes cultured for 13 days on a collagen matrix at the air-liquid interface. Immediately after arrival in the laboratory, the RHE were removed from the agarose-nutrient solution in the shipping multiwell plate under a sterile airflow. They were placed in a plate in which each well was previously filled with 2 mL EpiSkin ${ }^{\mathrm{TM}}$ maintenance or growth medium at room temperature. Samples were placed in the incubator at $37^{\circ} \mathrm{C}$, $5 \% \mathrm{CO}_{2}$ and saturated humidity, at least $24 \mathrm{~h}$ before incubation. EpiSkin ${ }^{\mathrm{TM}}$ (Lyon, France) furnished the assay medium used for incubations. RHE were topically treated first with DEPMPO $(20 \mu \mathrm{L}, 250$ $\mathrm{mM}$ in HEPES) and post incubated $\left(37^{\circ} \mathrm{C}, 5 \% \mathrm{CO}_{2}\right)$ during $15 \mathrm{~min}$. After the incubation time, the RHE were placed in the EPR tissue cell and the hydroperoxide (20 $\mu \mathrm{L}, 50 \mathrm{mM}$ in acetone) was applied to the epidermis taking care to ensure that the solution was only applied to it. EPR spectra were then recorded.

\section{EPR instrumentation}


EPR spectra were recorded on an EPR X-band spectrometer (ESP300E, Bruker Biospin GmbH, Germany), equipped with a high sensitivity resonator (4119HS-W1, Bruker Biospin GmbH, Germany). The $g$ calibration was performed using Bruker standard (strong pitch) with known isotropic $g$ factor of 2.0028. The principal experimental parameters values were: microwave power $5 \mathrm{~mW}$, modulation amplitude $0.5-1 \mathrm{G}$, and conversion time of ca. $160 \mathrm{~ms}$ resulting sweep time of ca. 3 min s for a single scan. Spectra were recorded at room temperature $(295 \mathrm{~K} \pm 1 \mathrm{~K})$. Regarding the investigations in solution, samples were introduced into glass capillaries (Hirschmann, $25 \mu \mathrm{L}$ ), sealed at both ends and transferred into the EPR cavity for measurement as fast as possible after reagents mixing. RHE were placed in an EPR tissue cell equipped with a silica window (Willmad, \#ER162TC-Q) and resulting EPR spectra recorded in situ right afterwards. Up to 10 scans were accumulated to improve the signal-to-noise ratio $(\mathrm{S} / \mathrm{N})$.

\section{EPR simulations}

All experimental spectra were analyzed by means of computer simulation using labmade scripts based on Easyspin toolbox under Matlab (Mathworks) environment [24]. Relevant ${ }^{14} \mathrm{~N},{ }^{1} \mathrm{H},{ }^{31} \mathrm{P},{ }^{13} \mathrm{C}$ hyperfine coupling constants $(h f c c s)$ of detected spin-adducts are listed in Table 1. Coupling constants in RHE were calculated following the best simulation attempts for such $\mathrm{S} / \mathrm{N}$.

\section{Results}

\section{EPR studies in solution}

Analyses in solution were initially carried out to evaluate radicals formed from ${ }^{13} \mathrm{C}$-substitued CumOOHs in comparison with previous studies we achieved with non-substituted CumOOH [21]. DEPMPO was chosen as the spin-trap since we observed previously that it allowed a broad view of all sort of radicals deriving from $\mathrm{CumOOH}$ [21]. Radical initiation was triggered by a catalytic amount of $\mathrm{Fe}(\mathrm{II})(0.1 \mathrm{mM})$ inducing a Fenton-like reaction. DEPMPO was employed in an excess concentration 
$(25 \mathrm{mM})$ with respect to ${ }^{13} \mathrm{C}$-substitued hydroperoxides $(0.54 \mathrm{mM})$. First studies were completed with mono-substituted ${ }^{13} \mathrm{C}-\mathrm{MeCumOOH}$ 1. Figure 2(c) shows the experimental EPR spectrum obtained. Computer simulation of the signal displayed a mixture of different spin-adducts formed by addition of transient short-lived radicals derived from 1 to the $\alpha$-carbon of DEPMPO nitronyl group. In agreement with our previous investigations on $\mathrm{CumOOH}$ [21], spin-adducts were identified through their hyperfine coupling constants $(h f c c s)[25,26]$ as originating from $\mathrm{HO}$ (Figure 2(e)), carbon centred radicals, probably methyl (Figure 2(f)), methoxy and/or possible peroxyl radicals (Figure 2(h)). But here, when compared to the non-substituted sample, an additional hyperfine splitting appeared (Figure $2(\mathrm{~g}))$, attributed to the presence of the paramagnetic probe of a ${ }^{13} \mathrm{C}$ nucleus with nuclear spin $\mathrm{I}=1 / 2$. Analysis of the spectrum leaded to $h f c c s$ values of $a_{\mathrm{N}}(\mathrm{G})=15.5, a_{\mathrm{H}}(\mathrm{G})=22.6, a_{\mathrm{P}}(\mathrm{G})=48.3$ and a new value $a_{13 \mathrm{C}}$ of $6.3 \mathrm{G}$ (Table 1 ). As only half of methyl radicals were ${ }^{13} \mathrm{C}$-substituted, it was possible to observe two spin-adducts corresponding to two types of carbon radicals trapped with similar $a_{\mathrm{N}}, a_{\mathrm{H}}$ and $a_{\mathrm{P}} h f c c s$, being either non-substituted (Figure 2(f)) or ${ }^{13} \mathrm{C}$-substituted (Figure $2(\mathrm{~g})$ ). There are only few examples in the literature describing $h f c c s$ for ${ }^{13} \mathrm{C}$ atoms, for example the description of $p$-benzyne radicals [27], $\beta$-substituted ethyl radicals [28] or some vinyl and allyl radicals [29]. However, no reference was found on $h f c c s$ values for the coupling with ${ }^{13} \mathrm{C}$ atoms on $\beta$ position of a nitroxide radical. Thus, to corroborate that ${ }^{13} \mathrm{C}$-methyl radicals had been trapped by DEPMPO, studies were conducted with di-substituted $\left({ }^{13} \mathrm{C}-\mathrm{Me}\right){ }_{2} \mathrm{CumOOH} 2$ having ${ }^{13} \mathrm{C}$-substituted methyl groups exclusively. Figure 3(c) shows the experimental EPR spectrum obtained. Here, computer simulation displayed a mixture of different spin-adducts formed again by trapping of $\mathrm{HO}^{\bullet}$ (Figure 3(e)), carbon centred (Figure 3(f)), methoxy and/or possible peroxyl radicals (Figure 3(g)). Yet, previously assigned DEPMPO- ${ }^{13} \mathrm{CH}_{3}$ spin-adduct was again detected in a relative higher proportion when compared to the studies performed with ${ }^{13} \mathrm{C}-\mathrm{MeCumOOH} 1$ and having very comparable $h f c c s$ values of $a_{\mathrm{N}}(\mathrm{G})=15.4$, $a_{\mathrm{H}}(\mathrm{G})=22.6, a_{\mathrm{P}}(\mathrm{G})=48.3$ and $a_{13 \mathrm{C}}(\mathrm{G})=6.4$. Thus, the relative intensity of the DEPMPO-carbon 
radical spin-adduct derived from $\mathrm{CumOOH}$ (Figure 4(a), star) was significantly reduced while introducing a single ${ }^{13} \mathrm{C}$-methyl group in the molecule of $\mathrm{CumOOH}$ (Figure 4(b)) and was suppressed in the case of doubly ${ }^{13} \mathrm{C}$ substitution (Figure $4(\mathrm{c})$ ), to the benefit of the spin-adduct corresponding to the ${ }^{13} \mathrm{C}$-methyl trapped (Figures 4(b)(c), black circle). These results supported that CumOOH derived carbon centred radicals were, in these experimental conditions, methyl radicals.

\section{EPR studies in reconstructed human epidermis}

In order to carry out the experiments, the RHE tissue was loaded beforehand with the spin-trap. As described previously in studies with tumour promoting peroxides [12], radicals formed from $\mathrm{CumOOH}$ in the skin model being both short lived and potentially generated at low concentrations, it was desirable for the spin-trap to be as close as possible to the site of radical generation prior to the topical application of the hydroperoxides. If similar EPR fingerprints to those of the experiments in solution were obtained, it was noticeable that other features did not fully overlay with any of the solution studies. Such differences can be explained by the much more complex system formed by the RHE when compared to simplified in solution investigations. Figure 4 shows the spectra obtained in solution along and in comparison with the spectra obtained in RHE for the three hydroperoxides tested. If the appearance of the spin-adduct resulting from trapping the radical ${ }^{13} \mathrm{C}$-substituted in RHE was barely visible when using ${ }^{13} \mathrm{C}-\mathrm{MeCumOOH} 1$ (Figure 4(f)), it became more evident with $\left({ }^{13} \mathrm{C}-\mathrm{Me}\right){ }_{2} \mathrm{CumOOH}$ 2 (Figure 4(g)). Major peaks could be assigned to DEPMPO-OH, DEPMPO- $\mathrm{CH}_{3}$ and DEPMPO- ${ }^{13} \mathrm{CH}_{3}$ spin-adducts by comparison with previous data in solution (Table 1) [21]. Again, the difference observed when comparing the $h f c c s$ values with those obtained in the EPR-ST solution studies could be explained by the distinct environment of the spin-adducts in solution compared to that of a complex heterogeneous tissue such as the RHE. Indeed, magnitudes of the $h f c c s$ pointing to the extent of delocalization of the unpaired electron over the molecule may be affected by the local spin environment and polarity. Moreover, control experiments were carried out for each compound by 


\begin{abstract}
simply incubating DEPMPO in the RHE and showed no EPR signal, corroborating that spin-adducts resulted from trapping radicals issued from the hydroperoxide. Also, after penetrating the RHE, CumOOH radical initiation has been induced by RHE matrix itself as no Fe(II) was supplemented, thus better mimicking real life exposure scenarios. These results suggested methyl radicals being formed in RHE after CumOOH exposure.
\end{abstract}

\title{
Discussion
}

In a recent work, we employed EPR-ST for the first time in the skin allergy field to study the potential of this methodology to investigate in situ the formation of free radicals from skin allergens in 3D RHE models [21]. CumOOH was used as proof of concept and we demonstrated the formation of carbon radicals in RHE. However, no evidence could be obtained concerning their specific nature. In the present work, this was investigated by using ${ }^{13} \mathrm{C}$-substitution as a tool to unravel which carbon radicals could be formed within the epidermis. As the major mechanism described for the formation of carbon radicals from $\mathrm{CumOOH}$ is $\beta$-scission of cumyl oxyl radicals affording methyl radicals, we developed the synthesis of $\mathrm{CumOOH}$ containing either one $\left({ }^{13} \mathrm{C}-\mathrm{MeCumOOH} \mathbf{1}\right)$ or both $\left(\left({ }^{13} \mathrm{C}-\mathrm{Me}\right){ }_{2} \mathrm{CumOOH} 2\right)$ methyl groups ${ }^{13} \mathrm{C}$-substituted and we further studied the formation of free radicals in solution and in RHE.

Preliminary studies in solution allowed setting up the optimal experimental conditions providing a decent signal-to-noise ratio while keeping low CumOOHs concentrations, i.e. suitable with physiological conditions. DEPMPO was chosen as an accurate spin-trap based upon (i) the high persistency of its superoxide and alkylperoxyl spin-adducts when compared to other spin-traps (e.g. DMPO); (ii) the clear distinction between oxygen- and carbon-derived spin-adducts [25, 30]. Radical initiation was performed via a $\mathrm{Fe}(\mathrm{II})$ Fenton-like reaction. As for $\mathrm{CumOOH}$, carbon centered, $\mathrm{CumO}^{\circ}$ and $\mathrm{HO}^{\bullet}$ radicals were identified for ${ }^{13} \mathrm{C}-\mathrm{MeCumOOH} 1$ and $\left({ }^{13} \mathrm{C}-\mathrm{Me}\right){ }_{2} \mathrm{CumOOH}$ 2. A new signal 
appeared in the case of mono-substituted 1 with $h f c c s a_{\mathrm{N}}(\mathrm{G})=15.5, a_{\mathrm{H}}(\mathrm{G})=22.6, a_{\mathrm{P}}(\mathrm{G})=48.3$ and $a_{13 \mathrm{C}}(\mathrm{G})=6.3$, whose fingerprint significantly increased in the case of the double-substituted compound 2, fully replacing the signal of carbon centered radicals trapped from non-substituted CumOOH. Thus, when all methyl groups were ${ }^{13} \mathrm{C}$-substituted, only DEPMPO- ${ }^{13} \mathrm{CH}_{3}$ spin-adducts were detected confirming that methyl radicals were the carbon-centered trapped radicals. This information was of high relevance for further studies in RHE.

RHE EpiSkin ${ }^{\mathrm{TM}}$ shows reasonable similarities to native human tissue in terms if morphology, stratum corneum presence, lipid composition and biochemical markers [22]. It is today a useful tool for testing irritation and penetration features of chemicals in contact with the skin as replacement of in vivo testing [31]. For our studies on skin allergy the availability of EpiSkin ${ }^{\mathrm{TM}}$ RHE is a very good alternative to the use of human and animal tissues as the model amends important legal and ethical issues. Although considerably more permeable than human skin on average, the model appears to be more consistent in permeability and responsiveness than human skin which is highly variable. Similar EPR-ST results were observed in $\mathrm{RHE}$ when testing $\mathrm{CumOOH},{ }^{13} \mathrm{C}-\mathrm{MeCumOOH} \mathbf{1}$ and $\left({ }^{13} \mathrm{C}\right.$ Me) ${ }_{2} \mathrm{CumOOH}$ 2. Though, new features in the RHE samples did not fully overlay with the reference spectra in solution and were ascribed to the complexity of the RHE system. Even if the S/N was significantly lower when compared to solution investigations and thus did not allow quantification of the spin-adducts, we can still suggest that methyl radicals issued from $\mathrm{CumOOH}$ decomposition can be formed in RHE EpiSkin ${ }^{\mathrm{TM}}$. Indeed, spectrum of the RHE experiment with twice ${ }^{13} \mathrm{C}$-labeled $\mathrm{CumOOH}$ (Figure $4(\mathrm{~g})$ ) was rather convincing as an additional spin-adduct assigned to DEPMPO- ${ }^{13} \mathrm{CH}_{3}$ spinadduct (black circles) was detected. Moreover, control experiments with DEPMPO, in absence of ${ }^{13} \mathrm{C}$ MeCumOOH 1 or $\left({ }^{13} \mathrm{C}-\mathrm{Me}\right)_{2} \mathrm{CumOOH} \mathrm{2,} \mathrm{did} \mathrm{not} \mathrm{exhibit} \mathrm{any} \mathrm{EPR} \mathrm{signal} \mathrm{(Figure} \mathrm{4(d)),} \mathrm{suggesting} \mathrm{that}$ the trapped ${ }^{\circ} \mathrm{CH}_{3}$ radicals originate from the hydroperoxide. Initially formed alkoxyl radicals derived from the $\mathrm{O}-\mathrm{O}$ bond cleavage and giving the ${ }^{\circ} \mathrm{CH}_{3}$ radicals by $\beta$-scission could also react with biomolecules in the RHE before DEPMPO trapping occurred. However, these potential side-reactions 
were not the purpose of the present study and will be part of future investigations. Worthy of note, no Fe(II) was used for radical initiation when probing RHE, to mimic real life skin allergy situation, whereas we previously showed that $\mathrm{Fe}(\mathrm{II})$ was required to initiate the free radical generation when mixing CumOOH and DEPMPO in solution [21]. As it is shown in Figure 5(d), no EPR signal was observed in the absence of $\mathrm{Fe}(\mathrm{II})$, whereas $0.1 \mathrm{mM} \mathrm{Fe}(\mathrm{II})$ was enough to initiate the radical reaction with a $\mathrm{Fe}(\mathrm{II})$ concentration dependent answer on the amount of spin-adducts formed. We can then hypothesize that reaction of organic peroxides in the skin in the presence of one-electron donor agents (i.e. amino and thiol groups present in amino acids, metal complexes, enzymes) may initiate the electron transfer processes and further skin proteins haptenation [32-34]. Also, the potential presence in the skin of $\mathrm{Fe}(\mathrm{III})$ heme-containing enzymes could be responsible for the peroxide O-O bond cleavage and start radical processes. Reactions of model Fe(III) porphyrin complexes with oxidants, such as peroxyacids and hydroperoxides, have been extensively studied as models. The cleavage has been confirmed but a clear mechanistic consensus has not evolved on the homolytic or heterolytic nature of the O-O bond cleavage by these species, both kinds of mechanisms being possible [35-37].

While skin allergens (haptens) are unable to stimulate an adaptive immune response after penetration into the epidermis, the immunogenicity is reached by reaction with skin proteins, to form stable antigenic conjugates recognized and processed for presentation to the immune system [38]. Therefore, the hapten-protein interaction is the primary key step to induce sensitization and was shown to occur relatively quickly in RHE [39]. The resulting sequence of events leading epidermal cells to present the antigen so formed to the immune system and its activation take 10 to 15 days in humans. The fast trapping by DEPMPO allowed EPR-ST characterization of the generated methyl radicals but the reaction with epidermal proteins was not evidenced. Thus, if we cannot testify so far that these radicals are the reacting species for the antigen formation we can strongly suggest their involvement. Additional tests to decipher their reactivity towards amino acids in the skin could be isolation from 


\begin{abstract}
RHE of modified proteins (reactivity in the absence of spin-trap) by sonication followed by mass spectrometry analysis and will be addressed in a near future.
\end{abstract}

\title{
Conclusion
}

This work shows by using ${ }^{13} \mathrm{C}$-substituted compounds and EPR-ST that the production of methyl radicals from $\mathrm{CumOOH}$ previously reported in isolated keratinocytes and other model systems is also possible in reconstructed skin tissue through a one-electron reductive pathway, and suggest that these methyl radicals could be involved in the antigen formation responsible for skin sensitization to CumOOH.

\section{Acknowledgements}

This work was part of the DEFCHEMSKALL Franco-German Collaborative International Research Project financially supported by the ANR (Agence Nationale de la Recherche; project no. ANR-15CE15-0023-01) and the DFG (Deutsche Forschungsgemeinschaft; project no. DFG, BL340/6-1). The authors thank the University of Strasbourg, the CNRS and the REseau NAtional de Rpe interDisciplinaire (RENARD, Fédération IR-RPE CNRS \#3443). 


\section{References}

[1] Yaremenko IA, Vil' VA, Demchuk DV, Terent'ev AO. Rearrangements of organic peroxides and related processes. Beilstein J Org Chem 2016; 12: 1647-1748.

[2] Rider CV, Chan P, Herbert RA, et al. Dermal exposure to cumene hydroperoxide: assessing its toxic relevance and oxidant potential. Toxicol Pathol 2016; 44: 749-762.

[3] Lai DY, Woo Y, Argus MF, Arcos JC. Carcinogenic potential of organic peroxides: prediction based on structure-activity relationships (SAR) and mechanism-based short-term tests. J Environ Sci Health Part C Environ Carcinog Ecotoxicol Rev 1996; 14: 63-80.

[4] Hanausek M, Walaszek Z, Viaje A, et al. Exposure of mouse skin to organic peroxides: subchronic effects related to carcinogenic potential. Carcinogenesis 2004; 25: 431-437.

[5] Brink A, Richter I, Lutz U, et al. Biological significance of DNA adducts: comparison of increments over background for various biomarkers of genotoxicity in L5178Y tk(+/-) mouse lymphoma cells treated with hydrogen peroxide and cumene hydroperoxide. Mutat Res 2009; 678: 123-128.

[6] Bråred Christensson J, Matura M, Bäcktorp C, Börje A, Nilsson JL, Karlberg AT. Hydroperoxides form specific antigens in contact allergy. Contact Dermatitis 2006; 55: 230-237.

[7] Lauricella R, Tuccio B. Détection et caractérisation de radicaux libres après piégeage de spins. In: La Spectroscopie de Résonance Paramagnétique Électronique, 2014, Bertrand P Ed. edp Sciences, Collection Grenoble Sciences, Les Ulis, France, pp. 49-78.

[8] He G, Samouilov A, Kuppusamy P, Zweier JL. In vivo EPR imaging of the distribution and metabolism of nitroxide radicals in human skin. J Magn Reson 2001; 148: 155-164.

[9] Jurkiewicz BA, Buettner GR. EPR detection of free radicals in UV-irradiated skin: mouse versus human. Photochem Photobiol 1996; 64: 918-922.

[10] Plonka PM. Electron paramagnetic resonance as a unique tool for skin and hair research. Exp Dermatol 2009; 18: 472-484.

[11] Taffe BG, Takahashi N, Kensler TW, Mason RP. Generation of free radicals from organic hydroperoxide tumor promoters in isolated mouse keratinocytes. J Biol Chem 1987; 262: 1214312149.

[12] Timmins GS, Davies MJ. Free radical formation in murine skin treated with tumour promoting organic peroxides. Carcinogenesis 1993; 14: 1499-1503.

[13] Timmins GS, Davies MJ. Free radical formation in isolated murine keratinocytes treated with organic peroxides and its modulation by antioxidants. Carcinogenesis 1993; 14: 1615-1620.

[14] Shvedova AA, Kisin ER, Murray AR, et al. Antioxidant balance and free radical generation in vitamin E-deficient mice after dermal exposure to cumene hydroperoxide. Chem Res Toxicol 2002; 15: 1451-1459.

[15] Shvedova AA, Kisin ER, Murray AR, et al. Pro/antioxidant status in murine skin following topical exposure to cumene hydroperoxide throughout the ontogeny of skin cancer. Biochemistry (Moscow) 2004; 69: 23-31.

[16] Sahli F, Silva e Sousa M, Vileno B, Lichter J, Lepoittevin JP, Blömeke B, Giménez-Arnau E. Understanding the skin sensitization capacity of ascaridole: a combined study of chemical reactivity and activation of the innate immune system (dendritic cells) on the epidermal environment. Arch Toxicol 2019, DOI: 10.1007/s00204-019-02444-3. 
[17] Kao D, Chaintreau A, Lepoittevin JP, Giménez-Arnau E. Synthesis of allylic hydroperoxides and EPR spin-trapping studies on the formation of radicals in iron systems as potential initiators of the sensitizing pathway. J Org Chem 2011; 76: 6188-6200.

[18] Kao D, Chaintreau A, Lepoittevin JP, Giménez-Arnau E. Mechanistic studies on the reactivity of sensitizing allylic hydroperoxides: investigation of the covalent modification of amino acids by carbon-radical intermediates. Toxicol Res 2014; 3: 278-289.

[19] Bråred-Christensson J, Johansson S, Hagvall L, Jonsson C, Börje A, Karlberg AT. Limonene hydroperoxide analogues differ in allergenic activity. Contact Dermatitis 2008; 59: 344-352.

[20] Deza G, García-Bravo B, Silvestre JF, Pastor MA, González-Pérez R, Heras-Mendaza F, Mercader P, Fernández-Redondo V, Niklasson B. Giménez-Arnau A, GEIDAC. Contact sensitization to limonene and linalool hydroperoxides in Spain: a GEIDAC prospective study. Contact Dermatitis 2017; 76: 74-80.

[21] Kuresepi S, Vileno B, Turek P, Lepoittevin JP, Giménez-Arnau E. Potential of EPR spin-trapping to investigate in situ free radicals generation from skin allergens in reconstructed human epidermis: cumene hydroperoxide as proof of concept. Free Radic Res 2018; 52: 171-179.

[22] Netzlaff F, Lehr CM, Wertz PW, Schaefer UF. The human epidermis models EpiSkin ${ }^{\circledR}$, SkinEthic ${ }^{\circledR}$ and EpiDerm ${ }^{\circledR}$ : an evaluation of morphology and suitability for testing phototoxicity, irritancy, corrosivity, and substance transport. Eur J Pharm Biopharm 2005; 60: 167-178.

[23] Barbati S, Clément JL, Olive G, Roubaud V, Tuccio B, Tordo P. In Minisci F. Ed. Free Radicals in Biology and Environment. Kluwer Academic Publishers, Dordrecht, The Netherlands, 1997, pp. 39-47.

[24] Stoll S, Schweiger A. EasySpin, a comprehensive software package for spectral simulation and analysis in EPR. J Magn Res 2006; 178: 42-55.

[25] Frejaville C, Karoui H, Tuccio B, et al. 5-(Diethoxyphosphoryl)-5-methyl-1-pyrroline- $N$-oxide: A new efficient phosphorylated nitrone for the in vitro and in vivo spin trapping of oxygen-centered radicals. J Med Chem 1995; 38: 258-265.

[26] Karoui H, Chalier F, Finet JP, Tordo P. DEPMPO: an efficient tool for the coupled ESR-spin trapping of alkylperoxyl radicals in water. Org Biomol Chem 2011; 9: 2473-2480.

[27] Usuki T, Mita T, Lear MJ, et al. Spin trapping of ${ }^{13} \mathrm{C}$-labeled $p$-benzynes generated by MasamuneBergman cyclization of bicyclic nine-membered enediynes. Angew Chem Int Ed 2004: 43; 52495253.

[28] Griller D, Ingold KU. On the conformation of $\beta$-substituted ethyl radicals. J Am Chem Soc 1974: 96; 6715-6720.

[29] Griller D, Cooper JW, Ingold KU. Kinetic applications of electron paramagnetic resonance spectroscopy. XVIII. Persistent vinyl, alkyl, and allyl radicals. J Am Chem Soc 1975: 97; 42694275.

[30] Stolze K, Udilova N, Nohl H. Spin trapping of lipid radicals with DEPMPO-derived spin traps: detection of superoxide, alkyl and alkoxyl radicals in aqueous and lipid phase. Free Radic Biol Med 2000; 29: 1005-1014.

[31] OECD testing guideline 439, 2015. In vitro skin irritation: RHE test method. DOI: 10.1787/9789264242845-en. 
[32] Moriarty-Craige SE, Jones DP. Extracellular thiols and thiol/disulphide redox in metabolism. Annu Rev Nutr 2004; 24: 481-509.

[33] Fujimoto A, Masuda T. Chemical interaction between polyphenols and a cysteinyl thiol under radical oxidation controls. J Agric Food Chem 2012; 60: 5142-5151.

[34] Grossi L. The mechanism of oxidation of aniline by peroxy-compounds: can EPR spectroscopy help to discriminate between one-electron transfer and a nucleophilic substitution process? Res Chem Intermed 1993; 19: 697-705.

[35] Traylor TJ, Kim C, Fann WP, Perrin CL. Reactions of hydroperoxides with iron (III) porphyrins: heterolytic cleavage followed by hydroperoxide oxidation. Tetrahedron 1998; 54: 7977-7986.

[36] Almarsson O, Bruice TC. A Homolytic mechanism of O-O bond scission prevails in the reactions of alkyl hydroperoxides with an octacationic tetraphenylporphinato-iron(III) complex in aqueous solution. J Am Chem Soc 1995; 117: 4533-4544.

[37] Labeque R, Marnett LJ. Homolytic and heterolytic scission of organic hydroperoxides by (mesotetraphenylporphinato)iron(III) and its relation to olefin epoxidation. J Am Chem Soc 1989; 111: 6621-6627.

[38] Lepoittevin JP. Molecular aspects in allergic and irritant contact dermatitis. In Johansen JD, Frosch PJ, Lepoittevin JP (Eds.) Contact Dermatitis $5^{\text {th }}$ Ed. Springer-Verlag, Berlin, Heidelberg, 2011, pp. 91-110.

[39] Elbayed K, Berl V, Debeuckelaere C, Moussallieh FM, Piotto M, Namer IJ, Lepoittevin JP. HRMAS NMR spectroscopy of reconstructed human epidermis: potential for the in situ investigation of the chemical interactions between skin allergens and nucleophilic amino acids. Chem Res Toxicol 2013; 26: 136-145. 


\section{Table 1}

Table 1. Hyperfine coupling constants (hfccs) of spin-adducts identified in solution (sol.) and in RHE*

\begin{tabular}{|c|c|c|c|c|c|c|}
\hline \multirow[t]{2}{*}{ Cpd. } & \multicolumn{5}{|c|}{ Coupling constants } & \multirow[t]{2}{*}{ Assignment } \\
\hline & $a_{\mathrm{N}}(\mathrm{G})$ & $a_{\mathrm{H}}(\mathrm{G})$ & $a_{\mathrm{P}}(\mathrm{G})$ & $a_{13 \mathrm{C}}(\mathrm{G})$ & $g$ & \\
\hline \multirow{3}{*}{$\begin{array}{l}\text { CumOOH } \\
\text { (sol.) [21] }\end{array}$} & 14.2 & 13.5 & 47.4 & & 2.0055 & DEPMPO-OH \\
\hline & 15.4 & 22.6 & 48.1 & & 2.0053 & DEPMPO-carbon R \\
\hline & 11.3 & 13.7 & 48.5 & & 2.0055 & $\begin{array}{l}\text { DEPMPO-OCH } \mathrm{H}_{3} \text { and/or } \\
\text { DEPMPO-OOCum }\end{array}$ \\
\hline \multirow[t]{4}{*}{1 (sol.) } & 14.2 & 13.3 & 47.3 & & 2.0056 & DEPMPO-OH \\
\hline & 15.4 & 22.6 & 48.0 & & 2.0053 & DEPMPO-carbon R \\
\hline & 15.5 & 22.6 & 48.3 & 6.3 & 2.0053 & DEPMPO- ${ }^{13} \mathrm{CH}_{3}$ \\
\hline & 11.3 & 13.7 & 48.2 & & 2.0055 & $\begin{array}{l}\text { DEPMPO-OCH } \mathrm{OH}_{3} \text { and/or } \\
\text { DEPMPO-OOCum }\end{array}$ \\
\hline \multirow[t]{3}{*}{2 (sol.) } & 14.2 & 13.4 & 47.4 & & 2.0053 & DEPMPO-OH \\
\hline & 15.4 & 22.6 & 48.3 & 6.4 & 2.0051 & DEPMPO- ${ }^{13} \mathrm{CH}_{3}$ \\
\hline & 11.6 & 14.4 & 48.1 & & 2.0055 & $\begin{array}{l}\text { DEPMPO-OCH } \mathrm{H}_{3} \text { and/or } \\
\text { DEPMPO-OOCum }\end{array}$ \\
\hline \multirow{2}{*}{$\begin{array}{l}\text { CumOOH } \\
\text { (RHE) }\end{array}$} & 12.5 & 13.6 & 46.0 & & 2.0064 & DEPMPO-OH \\
\hline & 14.8 & 21.4 & 48.0 & & 2.0058 & DEPMPO-carbon R \\
\hline \multirow[t]{3}{*}{1 (RHE) } & 12.9 & 13.7 & 46.0 & & 2.0064 & DEPMPO-OH \\
\hline & 14.5 & 21.2 & 47.3 & & 2.0056 & DEPMPO-carbon R \\
\hline & 14.9 & 21.6 & 47.9 & 6.2 & 2.0056 & DEPMPO- $-{ }^{13} \mathrm{CH}_{3}$ \\
\hline \multirow[t]{2}{*}{2 (RHE) } & 13.1 & 14.0 & 46.4 & & 2.0063 & DEPMPO-OH \\
\hline & 15.1 & 21.4 & 48.2 & 6.4 & 2.0059 & DEPMPO- ${ }^{13} \mathrm{CH}_{3}$ \\
\hline
\end{tabular}

* $h f c c s$ in RHE were calculated following the best simulation attempts considering the $\mathrm{S} / \mathrm{N}$ 


\section{Scheme 1}

1
2
3
4
5
6
7
8
9

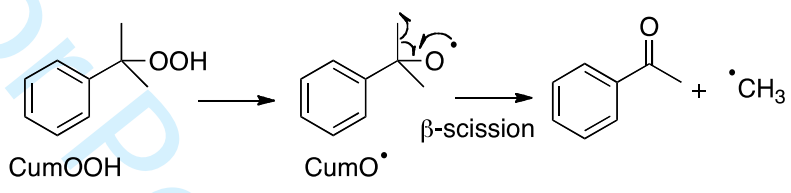




\section{Scheme 2}

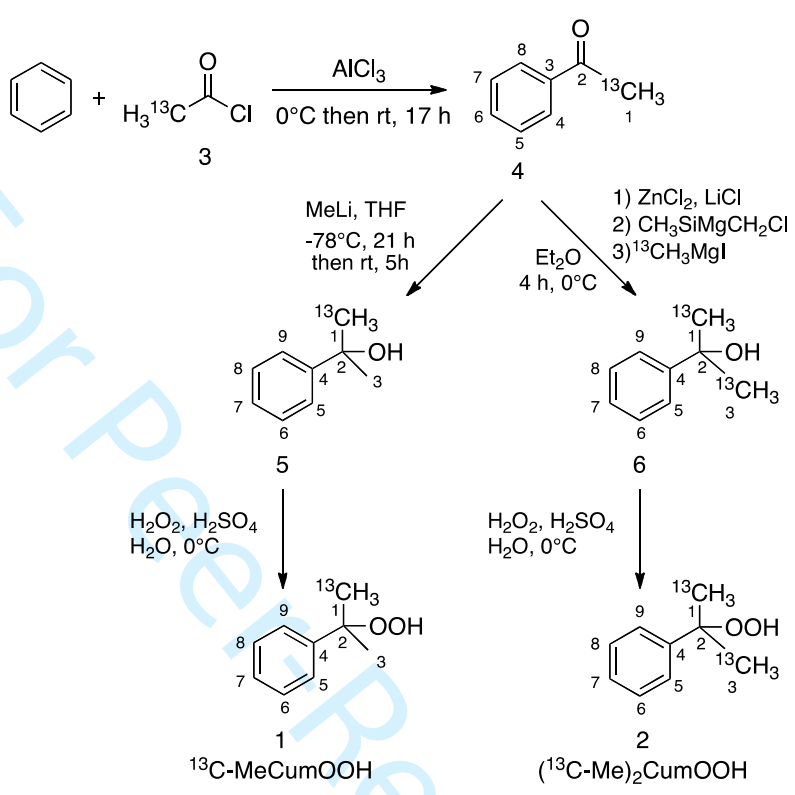

30

31 


\section{Figure 1}

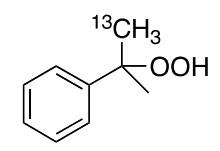

1

${ }^{13} \mathrm{C}-\mathrm{MeCumOOH}$

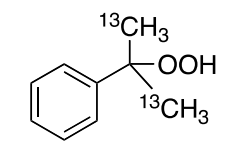

2

$\left({ }^{13} \mathrm{C}-\mathrm{Me}\right){ }_{2} \mathrm{CumOOH}$
16

17

18

19

20

21

22

23

24

25

26

27

28

29

30

31

32

33

34

35

36

37

38

39

40

41

42

43

44

45

46

47

48

49

50

51

52

53

54

55

56

57

58

59

60 
Figure 2

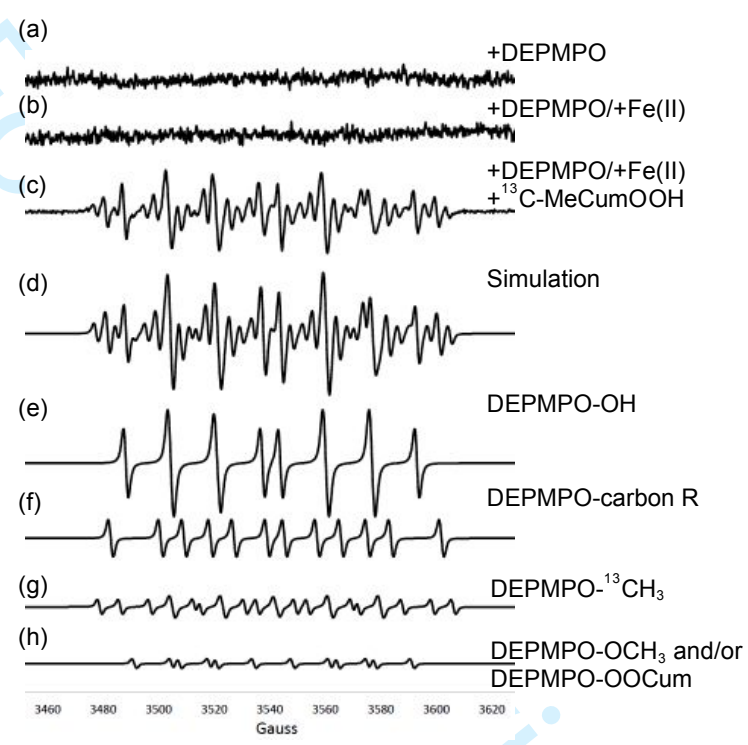




\section{Figure 3}
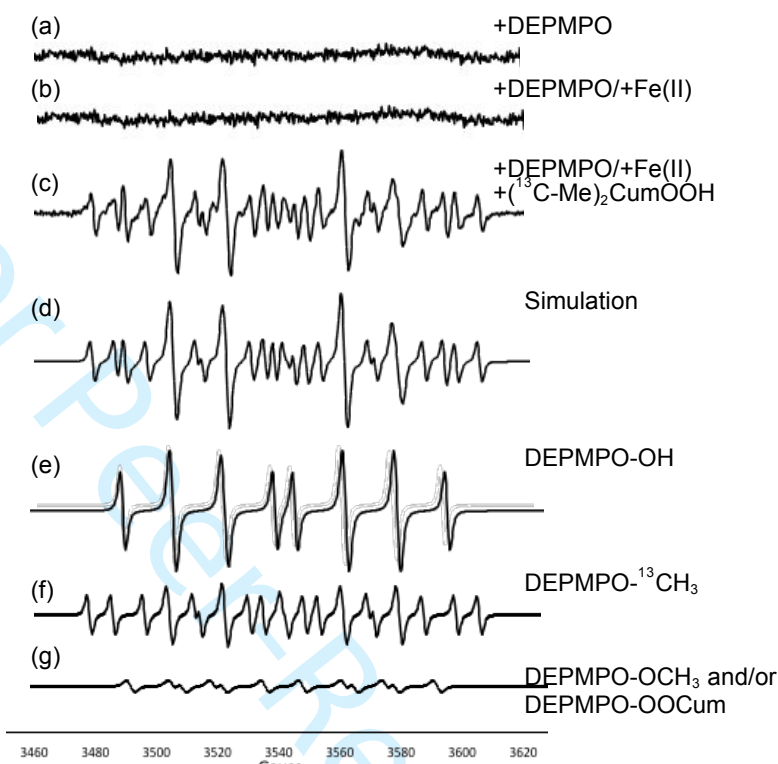
Figure 4

(a)

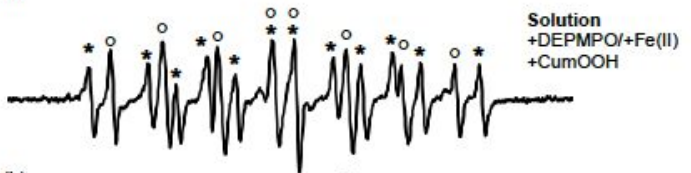

(b)

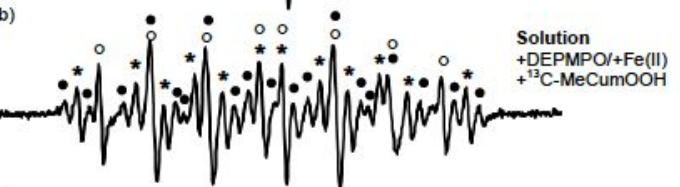

(c)

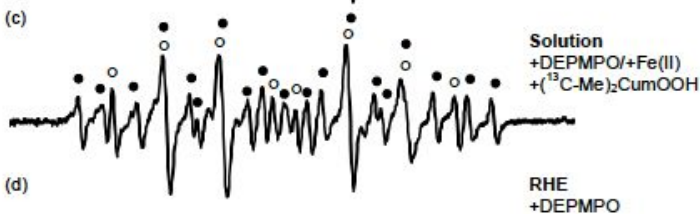

(0)

(e)
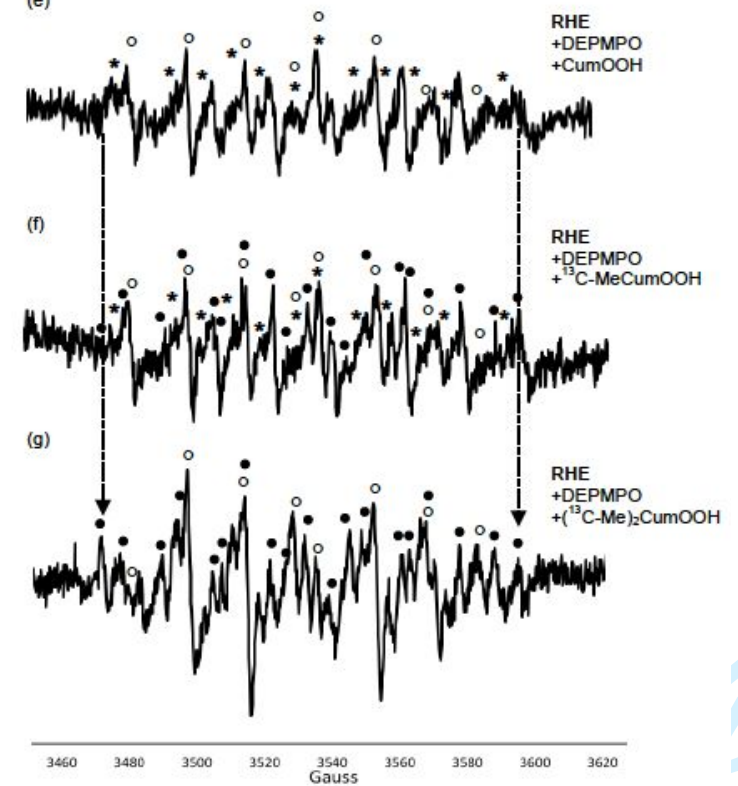
10

11

Figure 5

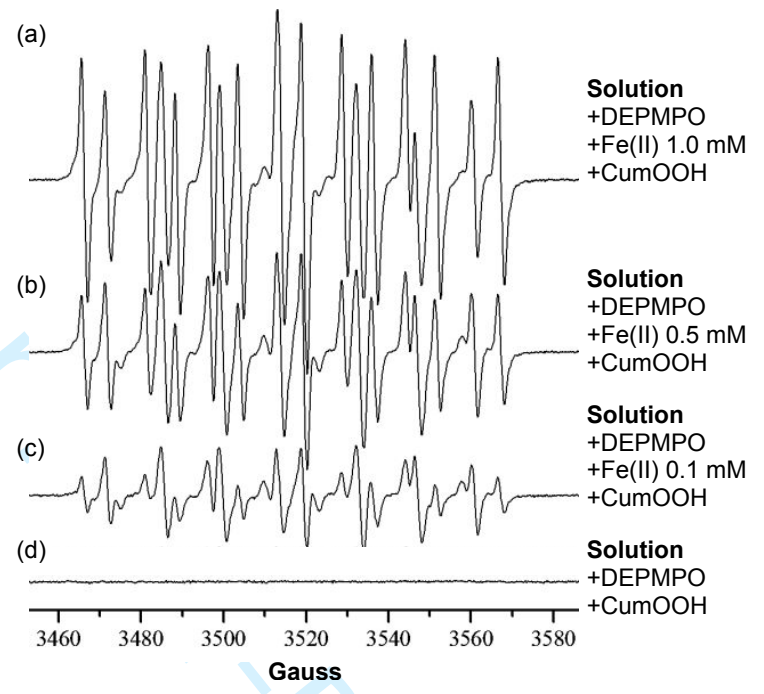




\section{Legends}

Scheme 1. Radical process leading to the formation of methyl radicals from $\mathrm{CumOOH}$.

Scheme 2. Synthetic pathway to obtain ${ }^{13} \mathrm{C}-\mathrm{MeCumOOH} 1$ and $\left({ }^{13} \mathrm{C}-\mathrm{Me}\right)_{2} \mathrm{CumOOH} 2.1-\left({ }^{13} \mathrm{C}\right)$ Acetophenone 4 was the key starting material for both compounds.

Figure 1. Chemical structures of ${ }^{13} \mathrm{C}-\mathrm{MeCumOOH} 1$ and $\left({ }^{13} \mathrm{C}-\mathrm{Me}\right)_{2} \mathrm{CumOOH} 2$.

Figure 2. EPR spectra of ${ }^{13} \mathrm{C}-\mathrm{MeCumOOH}$ 1/DEPMPO/Fe(II) in solution. (a) Control with single DEPMPO (25 $\mathrm{mM})$; (b) Control with DEPMPO (25 mM) and Fe(II) (1 mM); (c) Experimental spectrum obtained with ${ }^{13} \mathrm{C}$ MeCumOOH 1 (0.54 mM), DEPMPO (25 mM) and Fe(II) (0.1 mM); (d) Computer simulation of spectrum (c); (e-h) deconvolution of (d) with: (e) DEPMPO-OH spin-adduct (45\%); (f) DEPMPO-carbon R spin-adduct (28\%); (g) DEPMPO- ${ }^{13} \mathrm{CH}_{3}$ spin-adduct (23\%); (h) DEPMPO-OCH $\mathrm{D}_{3}$ and/or DEPMPO-OOCum spin-adduct $(4 \%)$.

Figure 3. EPR spectra of $\left({ }^{13} \mathrm{C}-\mathrm{Me}\right){ }_{2} \mathrm{CumOOH} 2 / \mathrm{DEPMPO} / \mathrm{Fe}(\mathrm{II})$ in solution. (a) Control with single DEPMPO (25 mM); (b) Control with DEPMPO (25 mM) and Fe(II) (1 mM); (c) Experimental spectrum obtained with $\left({ }^{13} \mathrm{C}-\mathrm{Me}\right)_{2} \mathrm{CumOOH} 2(0.54 \mathrm{mM})$, DEPMPO $(25 \mathrm{mM})$ and Fe(II) $(0.1 \mathrm{mM})$; (d) Computer simulation of spectrum (c); (e-g) deconvolution of (d) with: (e) DEPMPO-OH spin-adduct (55\%); (f) DEPMPO- ${ }^{13} \mathrm{CH}_{3}$ spinadduct (42\%); (g) DEPMPO-OCH 3 and/or DEPMPO-OOCum spin-adduct (3\%).

Figure 4. Comparative experimental EPR spectra in solution (a-c) and in RHE (d-g): (a) CumOOH (0.54 $\mathrm{mM}) / \mathrm{DEPMPO}(25 \mathrm{mM}) / \mathrm{Fe}(\mathrm{II})(0.1 \mathrm{mM})[21]$; (b) ${ }^{13} \mathrm{C}-\mathrm{MeCumOOH} 1$ (0.54 mM)/DEPMPO (25 mM)/Fe (II) $(0.1 \mathrm{mM})$; (c) $\left({ }^{13} \mathrm{C}-\mathrm{Me}\right)_{2} \mathrm{CumOOH} 2(0.54 \mathrm{mM}) / \mathrm{DEPMPO}(25 \mathrm{mM}) / \mathrm{Fe}$ (II) $(0.1 \mathrm{mM})$; (d) DEPMPO (250 mM)/RHE; (e) CumOOH (10 mM)/DEPMPO (250 mM)/RHE; (f) ${ }^{13} \mathrm{C}-\mathrm{MeCumOOH} 1$ (50 mM)/DEPMPO (250 $\mathrm{mM}) / \mathrm{RHE} ;(\mathrm{g})\left({ }^{13} \mathrm{C}-\mathrm{Me}\right)_{2} \mathrm{CumOOH} 2(50 \mathrm{mM}) / \mathrm{DEPMPO}(250 \mathrm{mM}) / \mathrm{RHE}$. Because of the low signal-to-noise ratio, DEPMPO-OCH $\mathrm{OH}_{3}$ and/or DEPMPO-OOCum spin-adducts are no indicated for clarification purposes. Spinadducts are indicated as follows: DEPMPO-OH white circle, DEPMPO- $\mathrm{CH}_{3}$ star and DEPMPO- ${ }^{13} \mathrm{CH}_{3}$ black circle. Dotted arrows indicate the formation of signals related to DEPMPO- ${ }^{13} \mathrm{CH}_{3}$ spin-adduct in RHE.

Figure 5. EPR experimental spectra in solution of CumOOH $(0.54 \mathrm{mM}) / \mathrm{DEPMPO}(25 \mathrm{mM})$ with varying concentrations of Fe (II): (a) Fe(II) $1.0 \mathrm{mM}$; (b) Fe(II) $0.5 \mathrm{mM}$; (c) Fe(II) $0.1 \mathrm{mM}$; (d) in the absence of Fe(II). 